\title{
Role of Reactive Oxygen Species in Hyper-Adrenergic
} Hypertension: Biochemical, Physiological, and Pharmacological Evidence from Targeted Ablation of the Chromogranin A (Chga) Gene

Jiaur R. Gayen, $\mathrm{PhD}^{1}{ }^{,}$, , Kuixing Zhang, $\mathrm{MD} / \mathrm{PhD}^{1}{ }^{1,}$, Satish P. RamachandraRao, $\mathrm{PhD}{ }^{1}$, Manjula Mahata, $\mathrm{PhD}^{1}$, Yuqing Chen, MD/PhD ${ }^{1}$, Hyung-Suk Kim, $\mathrm{PhD}^{3}$, Robert K. Naviaux, MD $^{1}$, Kumar Sharma, MD ${ }^{1,2}$, Sushil K. Mahata, PhD $^{1,2}$, and Daniel T. O'Connor, MD ${ }^{1,2}$ ${ }^{1}$ School of Medicine and Institute for Genomic Medicine, University of California at San Diego, 9500 Gilman Drive, La Jolla, CA 92093-0838

${ }^{2}$ VA San Diego Healthcare System, University of California at San Diego, 9500 Gilman Drive, La Jolla, CA 92093-0838

${ }^{3}$ Department of Pathology, University of North Carolina, Chapel Hill, NC 27599-7525

\section{Abstract}

Background-Oxidative stress, an excessive production of reactive oxygen species (ROS) outstripping antioxidant defense mechanisms, occurs in cardiovascular pathologies including hypertension. Here, we used biochemical, physiological, and pharmacological approaches to explore the role of derangements of catecholamines, ROS, and NO• in the development of a hyper-adrenergic model of hereditary hypertension: targeted ablation (knockout, KO) of chromogranin A (Chga) in the mouse.

Methods and Results-Homozygous (-/-) Chga gene knockout (KO) mice were compared to wild-type (WT, +/+) controls. In the KO mouse, elevations of systolic and diastolic BP were accompanied by not only elevated catecholamine (norepinephrine and epinephrine) concentrations, but also increased $\mathrm{ROS}\left(\mathrm{H}_{2} \mathrm{O}_{2}\right)$ and isoprostane (an index of lipid peroxidation), as well as depletion of $\mathrm{NO} \cdot$. Renal transcript analyses implicated changes in Noxl/2, Xo/Xdh, and Sodl, 2 mRNAs in ROS elevation by the KO state. $\mathrm{KO}$ alterations in BP, catecholamines, $\mathrm{H}_{2} \mathrm{O}_{2}$, isoprostane, and $\mathrm{NO} \bullet$ could be abrogated or even normalized (rescued) by either sympathetic outflow inhibition (with clonidine) or NADPH oxidase inhibition (with apocynin). In cultured renal podocytes, $\mathrm{H}_{2} \mathrm{O}_{2}$ production was substantially augmented by epinephrine (likely through $\mathrm{b}_{2}-$ adrenergic receptors) and modestly diminished by norepinephrine (likely through $\mathrm{a}_{1}$-adrenergic receptors).

Correspondence: Sushil K. Mahata, PhD or Daniel T. O'Connor, MD. Department of Medicine, UCSD 9500 Gilman Drive La Jolla, CA 92093-0838 Tel: 858-5340661 Fax: 858-5340626. smahata@ucsd.edu or doconnor@ucsd.edu Internet: http://hypertension.ucsd.edu.

Equal contributions.

Conflict of Interest Disclosures: None

This is a PDF file of an unedited manuscript that has been accepted for publication. As a service to our customers we are providing this early version of the manuscript. The manuscript will undergo copyediting, typesetting, and review of the resulting proof before it is published in its final citable form. Please note that during the production process errors may be discovered which could affect the content, and all legal disclaimers that apply to the journal pertain. 
Conclusions-ROS seem to play a necessary role in the development of hyper-adrenergic hypertension in this model, in a process mechanistically linking elevated BP with catecholamine excess, renal transcriptional responses, ROS elevation, lipid peroxidation, and NO• depletion. Some of the changes seem to be dependent on transcription, while others are immediate. The cycle could be disrupted by inhibition of either sympathetic outflow or NADPH oxidase. Since common genetic variation at the human $C H G A$ locus alters $\mathrm{BP}$, the results have implications for antihypertensive treatment as well as prevention of target-organ consequences of the disease. The results document novel pathophysiological links between the adrenergic system andc oxidative stress, and suggest new strategies to probe the role and actions of ROS within this setting.

\section{Keywords}

Chromogranin A; hypertension; reactive oxygen species; nitric oxide

\section{Introduction}

Increased sympathoadrenal activity plays a role in the development or maintenance of elevated blood pressure in both hypertensive patients and animal models of hypertension ${ }^{1-4}$. Chromogranin A (CHGA human, Chga rodent), the index member of the chromogranin/ secretogranin protein family, is co-stored and co-released with catecholamines from secretory vesicles in adrenal medulla ${ }^{5-7}$ and post-ganglionic sympathetic axons ${ }^{8}$. Although CHGA is over-expressed in human essential (hereditary) hypertension, the plasma concentration of its catestatin (catecholamine release-inhibitory) fragment ${ }^{9}$ is decreased in not only established cases of hypertension, but also still-normotensive subjects with a family history of hypertension ${ }^{10,11}$. Genetic variation at the human $C H G A$ locus predicts substantial alterations in $\mathrm{BP}^{12-14}$. Expanding upon the human findings, we found that Chga knockout $(\mathrm{KO},-/-)$ mice are hypertensive and hyper-adrenergic ${ }^{15}$. To get a better insight into the development of hypertension in $\mathrm{KO}$ mice we looked at the status of reactive oxygen species (ROS) and nitric oxide (NO) in these mice.

Oxidative stress, characterized by excessive production of reactive oxygen species (ROS) outstripping antioxidant defense mechanisms, has been associated with several cardiovascular pathologies including hypertension ${ }^{16,17}$, hypercholesterolemia, and diabetes. ROS are a family of short-lived, highly reactive byproducts of oxygen $\left(\mathrm{O}_{2}\right)$ metabolism. They include oxygen ions, free radicals, and peroxides, both inorganic and organic. ROS are generated by $\mathrm{O}_{2}$ metabolism through NADH dehydrogenase in mitochondria, as well as by specific oxidases, including NADPH oxidase (Nox), xanthine oxidase (Xdh/Xo) and arachidonic acid (AA)-metabolizing enzymes ${ }^{18}$. ROS may promote vascular smooth muscle cell contraction and proliferation, enhancing contraction in part by depleting the endothelium derived relaxing factor nitric oxide $(\mathrm{NO} \bullet)^{19}$.

In animal models, oxidative stress has been observed in the spontaneous (genetically) hypertensive rat $^{20}$, renovascular hypertension ${ }^{21}$, salt-sensitive hypertension ${ }^{22}$, and obesityinduced hypertension ${ }^{23}$. Although its pathogenesis is complex, human hypertension also displays signs of increased oxidative stress ${ }^{16,17,24,25}$, associated with a decreased antioxidant activity and a reduced ability to scavenge oxygen-derived free radicals ${ }^{26,} 27$. Indeed, enhanced ROS accumulation may be a heritable trait in hypertensive pedigrees ${ }^{17}$, with penetrance even before the onset of overt hypertension ${ }^{16}$.

In the present study, we explore the involvement of ROS and NO• in the development of a hyper-adrenergic model of hereditary hypertension: the Chga-KO mouse. Our results suggest a role for catecholamine excess in generating a hypertensive state partially 
consequent upon ROS activation and NO• depletion, a state amenable to pharmacological correction by inhibition of either adrenergic outflow or ROS generation.

\section{Methods}

\section{Targeted ablation of the Chga locus in the mouse}

Mice were studied according to a protocol approved by the Animal Subjects Committee of the University of California at San Diego, and research was conducted in accordance with institutional guidelines. Ablation of Chga gene was done as described previously ${ }^{15}$. The homozygous (-/-) Chga gene knockout (KO) mouse line was maintained and used for the experiments, and compared with wild-type (WT, +/+) strain controls; 5-6 month-old animals were studied from each strain. Based upon preliminary calculations of statistical power for BP, a threshold number of animals was included in each study, but we used as many animals as were available at each step from our local breeding colony (as many as 1012), to optimize our ability to find true positive and avoid false negative results.

\section{Renal podocyte cultures}

Since we found ROS changes in urine and kidney during hyper-adrenergic hypertension, we studied ROS generation by kidney podocytes, as a renal cell type in contact with urine as it is generated in Bowman's space. Conditionally immortalized mouse podocytes were a gift of Peter Mundel, and were cultured at $33^{\circ} \mathrm{C}$ in the presence of IFN- $\gamma$ as previously described ${ }^{28}$ for multiplication purposes, in the presence of mouse gamma interferon for 7 days until the cells reached $90 \%$ confluence. Podocytes were trypsinized at this point and split at 1:5 ratio for differentiation at $37^{\circ} \mathrm{C}$ for $8-10$ days without IFN- $\gamma$ in DMEM containing $5.5 \mathrm{mmol} / \mathrm{L}$ glucose and 5\% FCS. Differentiated podocytes were serum-starved overnight when confluent, and then used for the experiments.

\section{Biochemical measurements: Catecholamines, $\mathrm{H}_{2} \mathrm{O}_{2}$, isoprostane, creatinine, nitric oxide (NO•)}

Catecholamines-Catecholamines were measured in mouse plasma from anesthetized animals by high performance liquid chromatography (HPLC) (Waters 600E Multisolvent Delivery System; Waters, Milford, MA) using an electrochemical detector (ECD) (Waters 2465 Electrochemical Detector). Sample purification was done using activated alumina. The data were analyzed using Empower software from Waters, and catecholamine levels normalized according to the recovery of internal standard 3,4-dihydroxybenzylamine (DHBA) as previously described ${ }^{15}$.

$\mathrm{H}_{2} \mathrm{O}_{2}$-As a quantitative index of $\mathrm{H}_{2} \mathrm{O}_{2}$ generation, fluorescence generated by the Amplex Red reagent [10-acetyl-3,7-dihydroxyphenoxazine; Amplex Red Hydrogen Peroxide/ Peroxidase Assay Kit, Molecular Probes (A-22188); Invitrogen, Carlsbad, CA] was monitored. Amplex Red reacts with hydrogen peroxide in the presence of horseradish peroxidase (HRP) with 1:1 stoichiometry to form the fluorophore resorufin. Amplex Red and peroxidase in Kreb's Ringer phosphate buffer ( $\mathrm{pH}$ 7.4) were introduced into each well (podocyte or urine) in the dark. Catecholamines (epinephrine or norepinephrine) or synthetic adrenergic agonists (alpha-1: phenylephrine; alpha-2: clonidine; beta: isoproterenol) were tested for effects on $\mathrm{H}_{2} \mathrm{O}_{2}$ production in podocytes. The contents of the plate were incubated at $37^{\circ} \mathrm{C}$ for $60 \mathrm{~min}$ before the commencement of the first cycle of measurement.

Fluorescence intensity of resorufin was kinetically recorded with excitation at $544 \mathrm{~nm}$ and emission of $590 \mathrm{~nm}$ at $37^{\circ} \mathrm{C}$, via fluorescent plate reader (POLARstar OPTIMA; BMG Labtech, Offenburg, Germany). Measurements were made over 10-20 cycles, at 19-67 sec/ cycle. The data are reported as the mean value from each well over the recording period, with $\mathrm{n}=6$ wells per experimental condition. $\mathrm{H}_{2} \mathrm{O}_{2}$ levels were also measured in mouse urine, 
and then normalized by urine creatinine values, or in kidney cortex homogenate, with normalization to protein concentration in the same sample.

Nitric oxide-Urine or plasma nitric oxide (NO•) was measured according to manufacturer's protocol using a colorimetric assay kit for conversion of nitrate $\rightarrow$ nitrite by nitrate reductase, followed by quantification of nitrite with the Griess reaction and absorbance at $540 \mathrm{~nm}$ (Cayman Chemical, Ann Arbor, MI). Urinary NO• levels were normalized by urine creatinine values, or in kidney cortex homogenate, with normalization to protein concentration in the same sample.

Isoprostane-As an index of systemic oxidative stress, we used the urinary content of 8iso-PGF2 $\alpha$ (also known as 8-epi-PGF2 $\alpha$, or 15-isoprostane F2t) a stable product of arachidonic acid formed on non-enzymatic oxidation. Urinary isoprostane was measured using an ELISA kit (Northwest Life Science Specialties LLC, Vancouver, WA). The assay sensitivity was $50 \mathrm{pg}$, with a dynamic range of $0.1-10 \mathrm{ng} / \mathrm{ml}$, and the average intra-assay coefficient of variation for 24 replicate samples was $1.72 \%$. Cross-reactivities were undetectable $(<0.01 \%)$ for prostaglandins F2 $\alpha$, E2, D2, or arachidonic acid. The correlation between this ELISA method and GC/MS was $r=0.89$. Urinary isoprostane levels were normalized by urine creatinine values.

Creatinine-Diluted urine samples $(0.5 \mathrm{~mL})$ were mixed with $6 \mathrm{ml}$ water and $1 \mathrm{ml}$ saturated alkaline picrate solution. The mixture was kept for $45 \mathrm{~min}$ at $20^{\circ} \mathrm{C}$, absorbance measured at $505 \mathrm{~nm}$ and calculated using known standard concentrations.

\section{Blood pressure}

BP of mice was measured by the non-invasive tail-cuff method using the BP-2000 Blood Pressure Analysis System (Visitech Systems, Apex, NC < http://www.visitechsystems.com/ $>$ ), as previously described ${ }^{15}$. Mice were placed into individual rodent restraint holders on a preheated specimen platform at $38^{\circ} \mathrm{C}$ as measured by a LCD strip thermometer. For each treatment state, BP was measured at three sessions daily, between 1 PM to 3 PM, for 5 consecutive days (Mon $\rightarrow$ Fri). The first 2 days (Mon/Tues) were for acclimation of mice with the BP system, while data from the last 3 days (Wed/Thurs/Fri) were analyzed. At each of the 3 daily sessions, BP was measured 10 times in succession (with Visitech hardware/ software), and the results were averaged and saved as one measurement (with standard deviation) in a notebook computer running the BP analysis software package (Visitech Systems) via a PCMCIA data acquisition card. As per the manufacturer's protocol, BP readings having a standard deviation of less than $10 \mathrm{mmHg}$ were accepted for further analysis. We thus collected 9 measurements ( 3 days; 3 measurements/day) at each state for each mouse. Elevations of BP in the Chga(-/-) mouse can be detected by either this noninvasive method, or by implanted carotid transducers with telemetric monitoring ${ }^{15}$.

\section{Drug treatments}

Inhibition of sympathetic outflow-Clonidine $\mathrm{HCl}$ (C7897 at $>98 \%$ purity by TLC; Sigma-Aldrich, St. Louis, MO) was embedded in a clonidine-chow diet for rodents by Harlan-Teklad (Madison, WI), beginning with $1 \%$ (w/w) clonidine $\mathrm{HCl}$ in sucrose, and embedding in Harlan formula 5001 standard laboratory rodent diet, at $1 \mathrm{mg} / \mathrm{kg}$ chow. The dose was calculated to achieve delivery of $125 \mu \mathrm{g}$ clonidine $/ \mathrm{kg}$ body weight/day, and used for 3 weeks.

Inhibition of NADPH oxidase-Apocynin (acetovanillone, A10809 at $98 \%$ purity; Sigma-Aldrich, St. Louis, MO) was used at $2 \mathrm{mmol} / \mathrm{L}$ in drinking water for 3 weeks. 


\section{mRNA abundance by real-time RT-PCR}

Total RNA was extracted form one kidney of each mouse and real-time PCR was done with fluorescent reporter-tagged oligonucleotide primers on an ABI-7700 TaqMan platform (Life Technologies, Carlsbad, CA), with normalization of data to $\beta$-actin expression. $\mathrm{C}_{\mathrm{t}}$ (threshold cycle) is determined for both the specific target mRNA/cDNA as well as $\beta$-actin, and the difference in $\mathrm{C}_{\mathrm{t}}$ (from target mRNA versus $\beta$-actin mRNA) is normalized to the average for that state (e.g., control versus experimental), and expressed on a \% change (difference) scale.

\section{Renal cortex biochemistry}

Renal cortical homogenates were prepared from freshly harvested adult male kidneys (WT and $\mathrm{KO}$ ), and assayed for $\mathrm{H}_{2} \mathrm{O}_{2}$ and $\mathrm{NO} \cdot$, as described above. Results were normalized to homogenate protein concentration (Bradford Coomassie Brilliant Blue R-250 assay method; BioRad, Hercules, CA).

\section{Mitochondrial electron transport chain}

Mitochondria were prepared from freshly harvested adult male livers ( $n=3 \mathrm{WT}, \mathrm{n}=3 \mathrm{KO}$ ), as described ${ }^{29}$. Overall mitochondrial mass (per mg tissue protein) was indexed by citrate synthase activity, and electron transport chain enzymatic activity of mitochondrial complexes I, II, II/III, and IV was determined and normalized to citrate synthase activity as described $^{29}$.

\section{Statistical analyses}

Results are expressed as the mean value \pm one SEM (standard error of the mean). The reported "n" refers to the number of mice, rather than to the number of BP measurements taken (since, under each condition, BP was measured multiple times in each mouse, and then averaged for that mouse). Data were evaluated by ANOVA, followed by post hoc tests, in Excel (Microsoft, Bellevue, WA), Kaleidagraph (Synergy Software, Reading, PA) or SPSS-17 (Chicago, IL). MANOVA (multivariate ANOVA) was used to test the effect of strain on more than one dependent variable. Repeated measures (e.g., multiple BP values for each animal at each treatment state) were approached by linear mixed effect models (MIXED) in SPSS-17, to account for correlated data, factoring also for treatment. $P$ values less than 0.05 were considered statistically significant.

\section{Results}

\section{Chga ablation on $\mathrm{H}_{2} \mathrm{O}_{2}$ and lipid peroxidation (isoprostane) in urine and kidney}

Since increased ROS activity generates $\mathrm{H}_{2} \mathrm{O}_{2}{ }^{19}, 30$ with resulting lipid peroxidation (isoprostane) $)^{31}$, we measured $\mathrm{H}_{2} \mathrm{O}_{2}$ and isoprostane renal excretion, as well as $\mathrm{H}_{2} \mathrm{O}_{2}$ in kidney. Chga ablation caused significant increases in both urinary $\mathrm{H}_{2} \mathrm{O}_{2}$ and isoprostane excretions (Fig. 1A). There was a $\sim 20 \%$ increase in urinary isoprostane excretion in $\mathrm{KO}$ mice (10.33 \pm 0.51 vs $12.86 \pm 0.61 \mathrm{ng} / \mathrm{mg}$ creatinine, $\mathrm{p}<0.02$ ) (Fig. $1 \mathrm{~A}$ ), while urinary $\mathrm{H}_{2} \mathrm{O}_{2}$ excretion was $\sim 2.5$ times higher in the KO mice (1851.6 \pm 256.6 vs $4574.7 \pm 306.6$ fluorescence units/mg creatinine, $\mathrm{p}<0.002$ ) (Fig. 1A). MANOVA confirmed the simultaneous effect of mouse strain on the two oxidative traits ( $\mathrm{p}<8.55 \mathrm{E}-06)$. In renal cortex, $\mathrm{H}_{2} \mathrm{O}_{2}$ was elevated by $\sim 45 \%$ in the $\mathrm{KO}$ (on-line Fig. 1).

\section{Catecholamines on $\mathrm{H}_{2} \mathrm{O}_{2}$ in cultured glomerular podocytes}

Epinephrine caused a substantial increase $(\mathrm{p}<0.001)$ in $\mathrm{H}_{2} \mathrm{O}_{2}$ production, while norepinephrine caused a modest decrease (also $\mathrm{p}<0.001$ ) (Fig. 1B). When adrenergic receptor type-specific agonists were tested (Figure 1C), both the alpha-1 agonist 
phenylephrine $(\mathrm{p}<0.001)$ and the alpha-2 agonist clonidine reduced $\mathrm{H}_{2} \mathrm{O}_{2}$, while the beta agonist isoproterenol substantially increased $\mathrm{H}_{2} \mathrm{O}_{2}(\mathrm{p}<0.001)$. Since epinephrine displays preferential activity at beta- 2 receptors, epinephrine likely increases $\mathrm{H}_{2} \mathrm{O}_{2}$ production via beta- 2 activation $^{32}$; since norepinephrine displays preferential activity at alpha- 1 over alpha-2 receptors, norepinephrine likely inhibits $\mathrm{H}_{2} \mathrm{O}_{2}$ production via alpha-1 activation ${ }^{32}$.

\section{Sympathetic outflow inhibition (clonidine) on BP}

Chga ablation caused substantial elevations of both systolic ( $\mathrm{p}<0.0001)$ and diastolic $(\mathrm{p}<0.003) \mathrm{BP}^{15}$ (Fig. 2). 3 weeks of sympatho-inhibitory treatment with the $\alpha_{2}$-adrenergic agonist clonidine caused significant reductions of both SBP (by $\sim 9.1 \mathrm{mmHg}$; from $139.3 \pm 1.8$ to $130.2 \pm 2.7 \mathrm{mmHg}, \mathrm{p}<0.02$ ) and DBP (by $\sim 9.9 \mathrm{mmHg}$; from $101.1 \pm 2.6$ to $91.2 \pm 3.3 \mathrm{mmHg}, \mathrm{p}<0.03$ ) in the KO mice (Fig. 2 ), and the effects on DBP virtually normalized the trait.

\section{NADPH oxidase (Nox) inhibition (apocynin) on BP}

After treatment of the KO with the NADPH oxidase inhibitor apocynin for 3 weeks, SBP was reduced by $\sim 10.9 \mathrm{mmHg}$ (from $139.3 \pm 1.8$ to $128.4 \pm 2.0 \mathrm{mmHg}$, $\mathrm{p}<0.001$ ) while DBP fell by $\sim 11.2 \mathrm{mmHg}$ (from $101.1 \pm 2.6$ to $89.9 \pm 2.5 \mathrm{mmHg}$, p<0.007) (Fig. 2), and the effects on DBP virtually normalized the trait.

\section{BP repeated measures}

At each state (strain, treatment), BP was analyzed from 9 sets of measurements in each animal ( 3 days, 3 times/day). To account statistically for correlated values during repeated BP determinations, we also used a linear mixed effect model, specifying random effect per mouse. Treatment effects on SBP ( $\mathrm{F}=40.3, \mathrm{p}=2.8 \mathrm{E}-11)$ and DBP $(\mathrm{F}=11.9, \mathrm{p}=1.7 \mathrm{E}-7)$ remained significant. Repeated measures ANOVA also yielded significant effects for treatment regimens.

\section{Renal mRNA expression}

NADPH oxidase (Nox) mRNA abundance in kidney-Relative abundance of all isoforms of Nox mRNA were examined by real-time PCR and normalized to $\beta$-actin. In KO mice, Noxl and Nox 2 were significantly over-expressed by $\sim 4.7$ - and $\sim 0.8$-fold respectively compared to WT mice (Fig. 3A). There were no significant differences in Nox3 or Nox4 mRNA abundance, while $p 22$ Phox $(C y b a)$ was actually reduced in the KO by $\sim 40 \%$ $(\mathrm{p}=0.001)$ (Fig. 3A).

Other RedOx enzymes $-X d h / X o$ expression was also augmented by $\sim 0.7$-fold ( $\mathrm{p}=0.03$ ) in the KO (Fig. 3B). Sodl was reduced in the KO by $\sim 30 \%$ ( $\mathrm{p}=0.009$ ), as was $\operatorname{Sod} 2$ (by $\sim 40 \%$, p <0.0001), though not $\operatorname{Sod} 3$ ( $\mathrm{p}=0.207$ ) (Fig. 3B).

Nitric oxide synthases (Nos isoforms) - Nos3 (eNos) was increased by $\sim 0.6$-fold $(\mathrm{p}=0.0154)$ in the KO; Nos 1 (nNos) was increased marginally ( $\mathrm{p}=0.073$ ), while Nos 2 (bNos) was unchanged ( $\mathrm{p}=0.929)$ (Fig. 3C).

\section{Response of ROS to drug treatment: Clonidine or apocynin}

ROS were reduced significantly in KO mice either by sympathetic inhibition $\left(\alpha_{2}\right.$-agonist: clonidine) or NADPH oxidase blockade (Nox inhibitor: apocynin).

Clonidine-Treatment with clonidine for 3 weeks reduced urinary $\mathrm{H}_{2} \mathrm{O}_{2}$ excretion significantly in KO mice (from $4574.7 \pm 306.6$ to $3023.4 \pm 400.4$ fluorescence units $/ \mathrm{mg}$ creatinine, $\mathrm{p}<0.02$ ), a value comparable to the WT level (Fig. 4A). 
Apocynin-3 weeks of apocynin also corrected the elevated urinary $\mathrm{H}_{2} \mathrm{O}_{2}$ excretion in $\mathrm{KO}$ mice (from $4574.4 \pm 306.6$ to $2389.2 \pm 376.7$ fluorescence units/mg creatinine, $\mathrm{p}<0.005$ ), once again comparable to the WT level (Fig. 4A). In KO kidney cortex, apocynin decreased $\mathrm{H}_{2} \mathrm{O}_{2}$ by $\sim 31 \%$ (on-line Fig. 1).

\section{Response of lipid peroxidation (isoprostane) to drug treatment: Clonidine or apocynin}

Elevated ROS may activate lipid peroxidation, indexed by isoprostane from arachidonic acid. Formation of isoprostane was reduced significantly in $\mathrm{KO}$ mice either by sympathetic inhibition ( $\alpha_{2}$-agonist: clonidine) or NADPH oxidase blockade (Nox inhibitor: apocynin).

Clonidine-3 weeks of oral clonidine reduced urine isoprostane excretion significantly in KO mice (from $12.86 \pm 0.61$ to $9.78 \pm 0.99 \mathrm{ng} / \mathrm{mg}$ creatinine, $\mathrm{p}<0.04$ ), which is comparable to WT (Fig. 4B).

Apocynin-Treatment with apocynin for 3 weeks also reduced urinary isoprostane excretion in $\mathrm{KO}$ mice (from $12.86 \pm 0.61$ to $7.81 \pm 0.81 \mathrm{ng} / \mathrm{mg}$ creatinine, $\mathrm{p}<0.01$ ), a final value even lower than that seen in WT mice $(10.33 \pm 0.51 \mathrm{vs} 7.81 \pm 0.81 \mathrm{ng} / \mathrm{mg}$ creatinine, $\mathrm{p}<0.04)$ (Fig. 4B).

\section{Adrenergic over-activity: Response to drug treatment by clonidine or apocynin}

In KO mice, circulating catecholamines were significantly higher than in WT (norepinephrine: $4.22 \pm 0.50$ vs $2.21 \pm 0.33 \mathrm{ng} / \mathrm{ml}$, $\mathrm{p}<0.006$; epinephrine: $1.19 \pm 0.07 \mathrm{vs}$ $0.81 \pm 0.08 \mathrm{ng} / \mathrm{ml}, \mathrm{p}<0.005$ )(Fig. $4 \mathrm{C}$ ).

Clonidine-Treatment with clonidine corrected the elevated catecholamine levels in $\mathrm{KO}$ mice (norepinephrine: from $4.22 \pm 0.50$ to $2.62 \pm 0.45 \mathrm{ng} / \mathrm{ml}, \mathrm{p}<0.04$; epinephrine: from $1.19 \pm 0.07$ to $0.90 \pm 0.10 \mathrm{ng} / \mathrm{ml}, \mathrm{p}<0.04$ ), thus returning to levels that are comparable to WT (Fig. 4C).

Apocynin-3 weeks of apocynin also reduced catecholamine levels in KO mice (norepinephrine: from $4.22 \pm 0.50$ to $2.01 \pm 0.42 \mathrm{ng} / \mathrm{ml}$, $\mathrm{p}<0.01$; epinephrine: from $1.19 \pm 0.07$ to $0.86 \pm 0.12 \mathrm{ng} / \mathrm{ml}, \mathrm{p}<0.04$ ), once a again achieving levels that are comparable to the WT (Fig. 4C).

\section{Nitric oxide (NO-) depletion: Response to drug treatment by clonidine or apocynin}

In KO mice urine NO• excretion was reduced by $\sim 50 \%$ as compared to WT $(3273 \pm 193$ vs $1546 \pm 146 \mu-\mathrm{mol} / \mathrm{mg}$ creatinine, $\mathrm{p}<0.001$ ) (Fig. 4D). In kidney cortex, NO• was reduced by $\sim 33 \%$ in the $\mathrm{KO}$ (on-line Fig. 1). Likewise, KO mice also displayed a reduction of circulating (plasma) $\mathrm{NO} \bullet$ by $\sim 23 \%$ (from $24.8 \pm 2.0$ to $19.1 \pm 1.5 \mathrm{nmol} / \mathrm{ml}, \mathrm{p}<0.036$ ) (Fig. 4E).

Clonidine-Clonidine "rescued" the NO• depletion in KO mice (renal excretion: from $1546 \pm 146$ to $3231 \pm 416 \mu \mathrm{mol} / \mathrm{mg}$ creatinine, $\mathrm{p}<0.002$ ), which is comparable with WT (Fig. 4D). Likewise, clonidine increased circulating $\mathrm{NO} \bullet$ (from $19.1 \pm 1.5$ to $28.3 \pm 2.7 \mathrm{nmol} / \mathrm{ml}$, $\mathrm{p}<0.01$ ), and the resulting level of $\mathrm{NO} \bullet$ in plasma after clonidine treatment of $\mathrm{KO}$ mice was comparable to WT (Fig. 4E).

Apocynin-After apocynin treatment in $\mathrm{KO}$ mice, $\mathrm{NO} \bullet$ renal excretion increased (from $1546 \pm 146$ to $2199 \pm 260 \mu-\mathrm{mol} / \mathrm{mg}$ creatinine, $\mathrm{p}<0.039$ ) to WT level (Fig. 4D).). In KO kidney cortex, apocynin increased NO $\bullet$ by $\sim 46 \%$ (on-line Fig. 1). Likewise, circulating NO• concentration increased (from $19.1 \pm 1.5$ to $26.2 \pm 2.6 \mathrm{nmol} / \mathrm{ml}, \mathrm{p}<0.03$ ), back to the WT level (Fig. 4E 


\section{Mitochondria}

There was a $28 \%$ decline in mitochondrial complex I activity in the $\mathrm{KO}$ animals (normalized to citrate synthase [CS] activity, from $318 \pm 24$ to $230 \pm 10$ units/CS unit, $\mathrm{p}<0.03$ ), but no changes in the activities of complex II, complex II-III, or complex IV. Overall mitochondrial mass, indexed by citrate synthase activity itself, was unchanged from WT to $\mathrm{KO}$ (from $0.269 \pm 0.009$ to $0.261 \pm 0.026$ units/mg protein, $\mathrm{p}=0.79$ ).

\section{Discussion}

Overview

Reactive oxygen species (ROS, such as $\mathrm{H}_{2} \mathrm{O}_{2}$ or $\mathrm{O}_{2}{ }^{-}$[superoxide anion]) are implicated in a variety of cellular inflammatory responses, including pathological changes in cardiovascular disease, aging, hypercholesterolemia, and diabetes. ${ }^{33}$ ROS synthesized by cytoplasmic/ membrane NADPH oxidases (Nox), mitochondrial NADH oxidases, or xanthine oxidase (Xo), are to some extent unavoidable byproducts of cellular respiration. Oxygen radicals resulting from increased ROS activity may cause cellular damage, for example in the form of peroxidation of arachidonic acid yielding isoprostanes ${ }^{34}$, which may themselves be vasoactive $^{35}$. Elevated ROS may deplete the endogenous vasodilator NO•, thereby leading to elevation of BP. Here we probed the role of ROS in the hyper-adrenergic hypertension created by targeted ablation of the Chga gene ${ }^{15}$.

\section{The sympathetic nervous system and CHGA in hypertension}

Studies in animal models of genetic hypertension ${ }^{36}$ as well as investigations in hypertensive patients ${ }^{13}$ suggest that elevated sympathoadrenal activity may play an important role in the pathogenesis of genetically determined blood pressure elevations. CHGA (a $\sim 48$-kDa acidic polypeptide) is targeted into the regulated secretory pathway ${ }^{37}$ and may act as an "on/off switch" in neuroendocrine cells to trigger secretory granule biogenesis ${ }^{38}{ }^{39}$, as well as the precursor of the catecholamine release-inhibitory peptide catestatin (human CHGA 9352-372; mouse Chga $364-384)^{9}$. We developed a mouse model of targeted Chga ablation to delineate the in vivo role of Chga. Our findings in the Chga-l- mouse confirmed the putative functions of $\mathrm{Chga}^{15}$ : Chga KO mice displayed extreme phenotypic changes including elevated BP, loss of diurnal BP variation, and evidence of disturbed storage/release of sympathochromaffin transmitters, with depleted adrenal but augmented plasma concentrations. Here we uncover additional pathogenic consequences of catecholamine excess in the model.

\section{ROS: Role in hypertension and renal disease}

While NADPH oxide-generated ROS were originally characterized biologically as "attack" molecules in the phagocyte antimicrobial response $\mathrm{e}^{40}$ or later as mediators of target organ damage in cardio-renal or metabolic disease ${ }^{41}$, increasingly roles for ROS in autonomic signaling have been described. For example, recent evidence suggests that NADPH oxidases may mediate central nervous system control of sympathetic outflow ${ }^{42-44}$, and roles for NAPDH and ROS in signal transduction for several adrenergic receptors have been explored, including alpha- $1^{45-47}$, alpha- $2^{48}$, beta- $2^{49}$, and dopamine ${ }^{50}$.

Since we found ROS changes in urine and kidneys during hyper-adrenergic hypertension, we studied ROS generation by podocytes, a renal cell type in contact with urine as it is generated from the glomerulus in Bowman's space. In the renal podocyte ${ }^{51}$, cellular functions (such ion currents, signal transduction) are also influenced by adrenergic agonists, especially alpha- 1 and beta-2 adrenergic agonists ${ }^{52,53}$, yielding the potential for NADPH/ ROS signaling in the podocyte (Fig. 1B), as well. The selective effect of epinephrine to 
elevate $\mathrm{H}_{2} \mathrm{O}_{2}$ suggests involvement of a beta- 2 adrenergic receptor, while the decline by norepinephrine suggests an action on the alpha- 1 receptor ${ }^{32}$.

\section{Source of elevated ROS in hyper-adrenergic hypertension (on-line Table 1)}

We indexed ROS production principally by $\mathrm{H}_{2} \mathrm{O}_{2}$ excretion in urine (Fig. 1A). The net effect of Chga-/- to elevate ROS production would seem to involve the counterbalancing effects of several processes to both increase and decrease ROS (on-line Table 1). Two very proximate sources of elevated ROS became likely upon studies of renal transcripts: among Nox isoforms, Noxl and Nox2 (phagocyte form) were elevated, despite unchanged Nox3 and Nox4 (Renox) and an actual decline in the p22Phox (Cyba) subunit (which is shared across Nox $1 / 2 / 3 / 4)$. The Nox system is well described to catalyze the formation of superoxide $\left(\mathrm{O}_{2}^{-}\right)$by the pathway: $2 \mathrm{O}_{2}^{-}+2 \mathrm{H}_{2} \mathrm{O} \rightarrow 2 \mathrm{O}_{2}{ }^{-}+\mathrm{H}_{2} \mathrm{O}_{2}+\mathrm{OH}^{-}$; superoxide can then dismute (disproportionate) to $\mathrm{H}_{2} \mathrm{O}_{2}$ in a Sod-catalyzed pathway: $2 \mathrm{O}_{2}{ }^{-}+2 \mathrm{H}_{2} \mathrm{O} \rightarrow \mathrm{O}_{2}+\mathrm{H}_{2} \mathrm{O}_{2}+$ $2 \mathrm{OH}^{-} 2$. When the enzyme xanthine dehydrogenase (Xdh) is post-translationally modified to xanthine oxidase (Xo) by reversible disulfide oxidation ${ }^{54,55}$, it then catalyzes the formation of $\mathrm{H}_{2} \mathrm{O}_{2}$ by oxidation of hypoxanthine, bypassing $\mathrm{O}_{2}{ }^{-}$as follows: hypoxanthine $+\mathrm{H}_{2} \mathrm{O}+\mathrm{O}_{2}$ $\rightarrow$ xanthine $+\mathrm{H}_{2} \mathrm{O}_{2}$. Finally, even Nos itself (especially Nos3/eNos) can generate $\mathrm{O}_{2}{ }^{-}$, especially when its activity is "uncoupled" by shortage of its cofactor $\mathrm{BH}_{4}$ (tetrahydrobiopterin) $^{56}$.

Thus, at least three potential sources of ROS excess in Chga-l- emerge from transcriptional studies: elevations in mRNAs for Nox1/Nox2 (Fig. 3A), Xdh/XO and Nos3/eNos (since Nos3/eNos may give rise to $\mathrm{O}_{2}^{-}$when "uncoupled") (Fig. 3B). Furthermore, depletion of Sod1/Sod2 (Fig. 3B) would tend to sustain the duration of action of any ROS generated.

Apocynin inhibits Nox activity by interfering with the assembly of the Nox monomers into the final heteromultimeric active complex; normalization of elevated ROS by apocynin (Fig. $4 A \& B$ ) further implicates the Nox pathway in the excess ROS state of Chga-/-; although apocynin is a relatively low potency inhibitor of Nox 4 (Renox) ${ }^{57}$, the transcript abundance studies (Fig. 3A) suggest that, within Nox pathways, apocynin-sensitive isoforms Nox1/ Nox 2 are principally at work in the Chga-l- state.

At least two transcriptional changes would tend to decrease ROS in the Chga-/- state: decreased $p 22 P h o x / C y b a$ mRNA (since p22Phox is a shared subunit among Nox 1-4 isoforms), and increased catalase/Cat mRNA (since catalase catalyzes the reaction: $2 \mathrm{H}_{2} \mathrm{O}_{2}$ $\left.\rightarrow 2 \mathrm{H}_{2} \mathrm{O}+\mathrm{O}_{2}\right)$

Although mitochondria can also generate ROS, particularly $\mathrm{O}_{2}{ }^{-}$arising through incomplete $\mathrm{NADH}$-mediated reduction of $\mathrm{O}_{2}$ in complex I (by NADH dehydrogenase) or complex III (by coenzyme Q/cytochrome c reductase), here we found that overall mitochondrial mass was unchanged, and the activity of complex I was actually reduced $(\mathrm{p}<0.03)$, while the activities of complex II, complex II-III, or complex IV were unchanged. This reduction in complex I activity would have the effect of decreasing the electron flow and superoxide production in mitochondria, and may be seen as compensatory to increased superoxide production by Nox $1 / 2$.

\section{Origin of NO- depletion in hyper-adrenergic hypertension}

A likely scenario is that $\mathrm{O}_{2}{ }^{-}$generated by Nox activation $\left(2 \mathrm{O}_{2}+2 \mathrm{H}_{2} \mathrm{O} \rightarrow 2 \mathrm{O}_{2}{ }^{-}+\mathrm{H}_{2} \mathrm{O}_{2}+\right.$ $\left.\mathrm{OH}^{-}\right)$then depletes $\mathrm{NO} \bullet$ by forming peroxynitrite $\left(\mathrm{O}_{2}{ }^{-}+\mathrm{NO} \bullet \rightarrow \mathrm{ONO}_{2}{ }^{-}\right) . \mathrm{H}_{2} \mathrm{O}_{2}$ can also react with $\mathrm{NO} \bullet$ to produce singlet oxygen. ${ }^{58,59}$ While our measurements of $\mathrm{NO} \bullet$ were indirect ( $\mathrm{NO} \bullet \rightarrow \mathrm{NO}_{2} \rightarrow \mathrm{NO}_{3}$ quantified by the colorimetric Griess reaction), the results were directionally coordinate in urine and plasma (Fig. 4D\&E), and consistent with known responses of $\mathrm{NO} \bullet$ to oxygen radicals. 
By contrast, the enzymatic sources of NO•, Nos1/2/3, did not appear to be depleted in the $\mathrm{KO}$, at least at a transcriptional level: the renal transcript for Nos3 (eNos) was actually increased in the Chga-I- mouse ( $\mathrm{p}=0.0154)$, while Nos1 and Nos2 transcripts were unchanged (Fig. 3C). Nos enzymes are subject to post-translational modifications ${ }^{60}$, and we have no direct evidence to exclude post-translational inactivation of Nos enzymes. However, in the face of diminished NO• in the KO (Fig. 4D\&E), a predicted decline in Nos nitrosylation would be expected to increase Nos enzymatic activity ${ }^{60}$; likewise, elevated catecholamines in the $\mathrm{KO}$ (Fig. 4C) would be predicted to signal through protein kinases A and B to Nos phosphorylation and hence enzymatic activation ${ }^{61}$. Thus, it would be difficult to invoke known signaling pathways to postulate post-translational inactivation of Nos enzymes.

\section{Treatment implications}

Both sympathetic outflow inhibition with clonidine and NADPH oxidase inhibition with apocynin seemed to normalize the diverse phenotypes deranged in the Chga-l- state, including increased DBP, ROS excess, lipid peroxidation, catecholamine elevation, and NO• depletion (Fig. 4A-E). Since the Chga-/- model displays many features in common with human hypertension, and common genetic variation at the human $C H G A$ locus predicts changes in $\mathrm{BP}^{12}, 13$, these treatment results may prompt novel therapeutic strategies for human hypertension. Of note for pathophysiology, both agents (clonidine and apocynin) normalized not only DBP, but also ROS and catecholamine excess. These findings suggest that there may be bidirectional or reciprocal influences of catecholamines and ROS on each other's production. Why did clonidine and apocynin normalize DBP though not SBP in Chga-/- mice (Fig 2)? We evaluated only one dose for each drug, and cannot exclude the possibility that greater doses would normalize SBP as well. Alternatively, SBP elevations in the face of chronic (5-6 month) hypertension may involve structural adaptations of large arteries that cannot be completely reversed by only 3 weeks of treatment. Finally, the SBP elevation in Chga-/- mice may involve additional mechanisms that cannot be completely reversed by sympathetic outflow or NADPH inhibition.

\section{Advantages and limitations to this study}

Our experiments took advantage of a definitive biological reagent for evaluation of the consequences of Chga: i.e., the Chga-l- mouse. In this system, we were able to probe a spectrum of properties of the strain: molecular/transcriptional (mRNA profiling), biochemical (ROS, catecholamines, $\mathrm{NO} \bullet$, isoprostane), physiological (BP), and pharmacological (sympathetic blockade with clonidine, Nox blockade with apocynin). While our experiments point to a unifying explanation (Fig. 5) for the diverse adrenergic, oxidative, and nitroxidergic manifestations of the hypertension consequent upon Chga ablation, the work does raise new questions, both methodological and conceptual. We identified changes in several transcripts that might account for the oxidative consequences of Chga: Noxl/2, Xdh/Xo, Sodl/2, Nos3, and Cat. however, we do not yet understand the relative quantitative contributions of these gene products to the altered oxidative state in Chga-l- hypertension.

Clonidine acts centrally to effectively reduce sympathetic outflow (Fig. 4A-E), as evidenced by substantial reductions of elevated epinephrine and norepinephrine; however, we have not characterized the particular target-organ adrenergic receptors by which the elevated catecholamines exert their oxidative and nitroxidergic consequences, though the selective action of epinephrine (but not norepinephrine) to elevate podocyte $\mathrm{H}_{2} \mathrm{O}_{2}$ production (Fig. 1B, 1C) may implicate beta-2 (ADRB2) receptor subtypes ${ }^{32}$. Nor do we yet understand precisely how catecholamines' post-receptor signal transduction apparatus (heterotrimeric 
GTP-binding ["G"] proteins) might contact and influence expression of Nox, Nos, or Sod isoforms, or $\mathrm{Xdh} / \mathrm{Xo}$.

Catecholamines themselves can undergo base-catalyzed, non-enzymatic auto-oxidation, thereby generating ROS; indeed, antioxidant drugs may ameliorate catecholamine-mediated organ toxicity in some settings ${ }^{62}$. However, catecholamine oxidation is quite slow at physiological $\mathrm{pH}^{63}$, and plasma catecholamine concentrations are typically only in the high fM to $\mathrm{pM}$ range. In addition, catecholamine metabolism via monoamine oxidase (MAO) proceeds by oxidative deamination, yielding $\mathrm{H}_{2} \mathrm{O}_{2}{ }^{64}$. However, others have shown that ROS-mediated responses to catecholamines are mediated by adrenergic receptors ${ }^{65,} 66$.

Finally, we used the inhibitor apocynin to probe the role of Nox in these processes, since aopocynin is known to interfere with assembly of Nox monomers into active heteromultimeric enzymatic complexes; while apocynin has the advantages of previous characterization of its particular Nox enzymatic isoform targets ${ }^{57}$, and tolerability with administration in vivo (here, 3 weeks at $2 \mathrm{mM}$ in drinking water), a recent report suggests that apocynin may have other effects on oxidative pathways, such as a direct antioxidant (electron donor) property ${ }^{67}$.

Nonetheless, hypertension is perhaps the quantitatively most potent risk factor for cardiovascular disease ${ }^{68}$, and since common genetic variation at the $C H G A$ locus has substantial effects on BP in humans ${ }^{12-14}$, our results are likely to have implications for not only the pathogenesis but also the target organ consequences of human hypertension.

\section{Conclusions and perspectives}

Dysregulated ROS production has the potential to "hijack" physiological excitatory pathways (especially in brain) to elevate $\mathrm{BP}^{43}$. Such changes in ROS may result from catecholaminergic signaling ${ }^{42-50}$ (Fig. 1B\&C); thus, the catecholamine excess resulting from decline in Chga expression ${ }^{15}$ (Fig. 4C) may initiate the pathogenic ROS cascade (Fig. 5), in processes that are both transcriptional (Fig. 3) and at a level not requiring new mRNA or protein synthesis (Fig. 1B). Pharmacological disruption of this cascade, at the level of either sympathetic outflow or ROS synthesis, not only corrects disturbances in ROS (Fig. 4A\&B) and NO• (Fig. 4D\&E) production, but also normalizes elevated BP. Our results thus point to a role for novel pathways in the genesis and consequences of hypertension, and suggest new strategies for approaching the pathogenesis and treatment of hypertension, as well as the amelioration of its target organ consequences.

Oxidative stress, in which reactive oxygen species (ROS) outstrip antioxidant defenses, contributed to cardiovascular disease. In the present investigation, we studied derangements of ROS in the development of a hyper-adrenergic model of hereditary hypertension: targeted ablation (knockout, $\mathrm{KO}$ ) of chromogranin A (Chga) in the mouse. In the KO mouse, $\mathrm{BP}$ elevation was accompanied by not only catecholamine excess, but also by increased $\mathrm{ROS}\left(\mathrm{H}_{2} \mathrm{O}_{2}\right)$ and isoprostane levels (index of lipid peroxidation). Renal transcript analyses implicated changes in several redox enzymes. KO alterations in $\mathrm{BP}$ as well as biochemical traits could be abrogated by inhibition of either sympathetic outflow or of NADPH oxidase. In cultured renal podocytes, $\mathrm{H}_{2} \mathrm{O}_{2}$ production was augmented by epinephrine (likely through beta-2-receptors). Thus, ROS may play an important role in the development of hyper-adrenergic hypertension in this experimental model, in a process mechanistically linking elevated $\mathrm{BP}$ with catecholamine excess, renal transcriptional responses, ROS elevation, lipid peroxidation, and $\mathrm{NO} \bullet$ depletion. Overall, our results demonstrate the existence of novel pathophysiological links between the 
adrenergic system and oxidative stress, and suggest new strategies to probe the role and actions of ROS in this setting.

\section{Supplementary Material}

Refer to Web version on PubMed Central for supplementary material.

\section{Acknowledgments}

Funding Sources: This work was supported by grants from the Department of Veterans Affairs (SKM \& DTOC), the National Institutes of Health (R01 DA011311 to SKM; DK 60702 and MD000220 to DTOC; P01 HL58120, U01 HL69758 to SKM \& DTOC), and the Juvenile Diabetes Research Foundation (JDRF, to KS).

\section{Abbreviations}

$\begin{array}{ll}\text { BP } & \text { Blood pressure } \\ \text { CA } & \text { Catecholamines (epinephrine or norepinephrine) } \\ \text { Cat } & \text { Catalase } \\ \text { Chga } & \text { Chromogranin A (human CHGA, rodent Chga) } \\ \text { CS } & \text { Citrate synthase (index of mitochondrial mass) } \\ \text { KO } & \text { Knock-out (homozygous Chga-/-) } \\ \text { NO• } & \text { Nitric oxide } \\ \text { Nox } & \text { NADPH oxidase } \\ \text { O2 }^{-} & \text {Superoxide anion } \\ \text { Red/Ox } & \text { Reduction/Oxidation } \\ \text { ROS } & \text { Reactive oxygen species }\left(\mathrm{H}_{2} \mathrm{O}_{2} \text { or } \mathrm{O}_{2}^{-} \text {) }\right. \\ \text { WT } & \text { Wild-type (homozygous } \mathrm{Chga}^{-}++ \text {) } \\ \text { Xdh/Xo } & \text { Xanthine dehydrogenase/Xanthine oxidase }\end{array}$

\section{References}

1. Goldstein DS. Plasma catecholamines and essential hypertension. An analytical review. Hypertension 1983;5:86-99.

2. Westfall TC, Meldrum MJ. Alterations in the release of norepinephrine at the vascular neuroeffector junction in hypertension. Annu Rev Pharmacol Toxicol 1985;25:621-641. [PubMed: 3890711]

3. Borkowski KR, Quinn P. Adrenaline and the development of spontaneous hypertension in rats. J Auton Pharmacol 1985;5:89-100. [PubMed: 2862149]

4. Ohlstein EH, Kruse LI, Ezekiel M, Sherman SS, Erickson R, DeWolf WE Jr. Berkowitz BA. Cardiovascular effects of a new potent dopamine beta-hydroxylase inhibitor in spontaneously hypertensive rats. J Pharmacol Exp Ther 1987;241:554-559. [PubMed: 3572812]

5. Winkler H, Fischer-Colbrie R. The chromogranins A and B: The first 25 years and future perspectives. Neuroscience 1992;49:497-528. [PubMed: 1501763]

6. Taupenot L, Harper KL, O'Connor DT. Mechanisms of disease: The chromogranin-secretogranin family. New Engl J Med 2003;348:1134-1149. [PubMed: 12646671]

7. Montero-Hadjadje M, Vaingankar S, Elias S, Tostivint H, Mahata SK, Anouar Y. Chromogranins A and B and secretogranin II: Evolutionary and functional aspects. Acta Physiol (Oxf) 2008;192:309_ 324. [PubMed: 18005393] 
8. Takiyyuddin MA, Cervenka JH, Pandian MR, Stuenkel CA, Neumann HP, O'Connor DT. Neuroendocrine sources of chromogranin-A in normal man: Clues from selective stimulation of endocrine glands. J Clin Endocrinol Metab 1990;71:360-369. [PubMed: 2116438]

9. Mahata SK, O'Connor DT, Mahata M, Yoo SH, Taupenot L, Wu H, Gill BM, Parmer RJ. Novel autocrine feedback control of catecholamine release. A discrete chromogranin A fragment is a noncompetitive nicotinic cholinergic antagonist. J Clin Invest 1997;100:1623-1633. [PubMed: 9294131]

10. Takiyyuddin MA, Parmer RJ, Kailasam MT, Cervenka JH, Kennedy B, Ziegler MG, Lin MC, Li J, Grim CE, Wright FA, O'Connor DT. Chromogranin A in human hypertension. Influence of heredity. Hypertension 1995;26:213-220. [PubMed: 7607727]

11. O'Connor DT, Kailasam MT, Kennedy BP, Ziegler MG, Yanaihara N, Parmer RJ. Early decline in the catecholamine release-inhibitory peptide catestatin in humans at genetic risk of hypertension. $\mathrm{J}$ Hypertens 2002;20:1335-1345. [PubMed: 12131530]

12. Rao F, Wen G, Gayen JR, Das M, Vaingankar SM, Rana BK, Mahata M, Kennedy BP, Salem RM, Stridsberg M, Abel K, Smith DW, Eskin E, Schork NJ, Hamilton BA, Ziegler MG, Mahata SK, O'Connor DT. Catecholamine release-inhibitory peptide catestatin (chromogranin A(352-372)): Naturally occurring amino acid variant Gly364Ser causes profound changes in human autonomic activity and alters risk for hypertension. Circulation 2007;115:2271-2281. [PubMed: 17438154]

13. Chen Y, Rao F, Rodriguez-Flores JL, Mahata M, Fung MM, Stridsberg M, Vaingankar SM, Wen G, Salem RM, Das M, Cockburn MG, Schork NJ, Ziegler MG, Hamilton BA, Mahata SK, Taupenot L, O'Connor DT. Naturally occurring human genetic variation in the 3'-untranslated region of the secretory protein chromogranin $\mathrm{A}$ is associated with autonomic blood pressure regulation and hypertension in a sex-dependent fashion. J Am Coll Cardiol 2008;52:1468-1481. [PubMed: 19017515]

14. Chen Y, Rao F, Rodriguez-Flores JL, Mahapatra NR, Mahata M, Wen G, Salem RM, Shih PA, Das M, Schork NJ, Ziegler MG, Hamilton BA, Mahata SK, O'Connor DT. Common genetic variants in the chromogranin A promoter alter autonomic activity and blood pressure. Kidney Int 2008;74:115-125. [PubMed: 18432188]

15. Mahapatra NR, O'Connor DT, Vaingankar SM, Hikim AP, Mahata M, Ray S, Staite E, Wu H, Gu Y, Dalton N, Kennedy BP, Ziegler MG, Ross J, Mahata SK. Hypertension from targeted ablation of chromogranin A can be rescued by the human ortholog. J Clin Invest 2005;115:1942-1952. [PubMed: 16007257]

16. Lacy F, O'Connor DT, Schmid-Schonbein GW. Plasma hydrogen peroxide production in hypertensives and normotensive subjects at genetic risk of hypertension. J Hypertens 1998;16:291-303. [PubMed: 9557922]

17. Lacy F, Kailasam MT, O'Connor DT, Schmid-Schonbein GW, Parmer RJ. Plasma hydrogen peroxide production in human essential hypertension: Role of heredity, gender, and ethnicity. Hypertension 2000;36:878-884. [PubMed: 11082160]

18. Vanhoutte PM. Endothelium-derived free radicals: For worse and for better. J Clin Invest 2001;107:23-25. [PubMed: 11134174]

19. Wilcox CS. Reactive oxygen species: Roles in blood pressure and kidney function. Curr Hypertens Rep 2002;4:160-166. [PubMed: 11884272]

20. Wu L, Juurlink BH. Increased methylglyoxal and oxidative stress in hypertensive rat vascular smooth muscle cells. Hypertension 2002;39:809-814. [PubMed: 11897769]

21. Lerman LO, Nath KA, Rodriguez-Porcel M, Krier JD, Schwartz RS, Napoli C, Romero JC. Increased oxidative stress in experimental renovascular hypertension. Hypertension 2001;37:541546. [PubMed: 11230332]

22. Trolliet MR, Rudd MA, Loscalzo J. Oxidative stress and renal dysfunction in salt-sensitive hypertension. Kidney Blood Press Res 2001;24:116-123. [PubMed: 11435744]

23. Dobrian AD, Davies MJ, Schriver SD, Lauterio TJ, Prewitt RL. Oxidative stress in a rat model of obesity-induced hypertension. Hypertension 2001;37:554-560. [PubMed: 11230334]

24. Romero JC, Reckelhoff JF. State-of-the-art lecture. Role of angiotensin and oxidative stress in essential hypertension. Hypertension 1999;34:943-949. [PubMed: 10523389] 
25. Raij L. Nitric oxide in hypertension: Relationship with renal injury and left ventricular hypertrophy. Hypertension 1998;31:189-193. [PubMed: 9453301]

26. Ward NC, Croft KD. Hypertension and oxidative stress. Clin Exp Pharmacol Physiol 2006;33:872-876. [PubMed: 16922824]

27. McIntyre M, Bohr DF, Dominiczak AF. Endothelial function in hypertension: The role of superoxide anion. Hypertension 1999;34:539-545. [PubMed: 10523323]

28. Mundel P, Reiser J, Zuniga Mejia Borja A, Pavenstadt H, Davidson GR, Kriz W, Zeller R. Rearrangements of the cytoskeleton and cell contacts induce process formation during differentiation of conditionally immortalized mouse podocyte cell lines. Exp Cell Res 1997;236:248-258. [PubMed: 9344605]

29. Naviaux RK, Le TP, Bedelbaeva K, Leferovich J, Gourevitch D, Sachadyn P, Zhang XM, Clark L, Heber-Katz E. Retained features of embryonic metabolism in the adult mrl mouse. Mol Genet Metab 2009;96:133-144. [PubMed: 19131261]

30. Cuzzocrea S, Mazzon E, Dugo L, Di Paola R, Caputi AP, Salvemini D. Superoxide: A key player in hypertension. FASEB J 2004;18:94-101. [PubMed: 14718390]

31. Montero A, Munger KA, Khan RZ, Valdivielso JM, Morrow JD, Guasch A, Ziyadeh FN, Badr KF. $\mathrm{F}(2)$-isoprostanes mediate high glucose-induced tgf-beta synthesis and glomerular proteinuria in experimental type I diabetes. Kidney Int 2000;58:1963-1972. [PubMed: 11044216]

32. Alexander SP, Mathie A, Peters JA. Guide to receptors and channels (grac), 3rd edition. Br J Pharmacol 2008;153(Suppl 2):S1-209. [PubMed: 18347570]

33. Keaney JF Jr. Larson MG, Vasan RS, Wilson PW, Lipinska I, Corey D, Massaro JM, Sutherland P, Vita JA, Benjamin EJ. Obesity and systemic oxidative stress: Clinical correlates of oxidative stress in the framingham study. Arterioscler Thromb Vasc Biol 2003;23:434-439. [PubMed: 12615693]

34. Morrow JD. Quantification of isoprostanes as indices of oxidant stress and the risk of atherosclerosis in humans. Arterioscler Thromb Vasc Biol 2005;25:279-286. [PubMed: 15591226]

35. Krier JD, Rodriguez-Porcel M, Best PJ, Romero JC, Lerman A, Lerman LO. Vascular responses in vivo to 8-epi pgf(2alpha) in normal and hypercholesterolemic pigs. Am J Physiol Regul Integr Comp Physiol 2002;283:R303-308. [PubMed: 12121841]

36. O'Connor DT, Takiyyuddin MA, Printz MP, Dinh TQ, Barbosa JA, Rozansky DJ, Mahata SK, Wu H, Kennedy BP, Ziegler MG, Wright FA, Schlager G, Parmer RJ. Catecholamine storage vesicle protein expression in genetic hypertension. Blood Press 1999;8:285-295. [PubMed: 10803489]

37. Kelly RB. Pathways of protein secretion in eukaryotes. Science 1985;230:25-32. [PubMed: 2994224]

38. Kim T, Tao-Cheng J, Eiden LE, Loh YP. Chromogranin A, an "On/off” Switch controlling densecore secretory granule biogenesis. Cell 2001;106:499-509. [PubMed: 11525735]

39. Courel M, Rodemer C, Nguyen ST, Pance A, Jackson AP, O'Connor DT, Taupenot L. Secretory granule biogenesis in sympathoadrenal cells: Identification of a granulogenic determinant in the secretory prohormone chromogranin A. J Biol Chem 2006;281:38038-38051. [PubMed: 17032650]

40. Nauseef WM. Biological roles for the Nox family Nadph oxidases. J Biol Chem 2008;283:1696116965. [PubMed: 18420576]

41. Bedard K, Krause KH. The Nox family of ros-generating Nadph oxidases: Physiology and pathophysiology. Physiol Rev 2007;87:245-313. [PubMed: 17237347]

42. Gao L, Wang W, Li YL, Schultz HD, Liu D, Cornish KG, Zucker IH. Sympathoexcitation by central Ang II: Roles for At1 receptor upregulation and Nad(p)h oxidase in Rvlm. Am J Physiol Heart Circ Physiol 2005;288:H2271-2279. [PubMed: 15637113]

43. Peterson JR, Sharma RV, Davisson RL. Reactive oxygen species in the neuropathogenesis of hypertension. Curr Hypertens Rep 2006;8:232-241. [PubMed: 17147922]

44. Infanger DW, Sharma RV, Davisson RL. Nadph oxidases of the brain: Distribution, regulation, and function. Antioxid Redox Signal 2006;8:1583-1596. [PubMed: 16987013]

45. Yamaguchi O, Kaneshiro T, Saitoh S, Ishibashi T, Maruyama Y, Takeishi Y. Regulation of coronary vascular tone via redox modulation in the alpha1-adrenergic-angiotensinendothelin axis of the myocardium. Am J Physiol Heart Circ Physiol 2009;296:H226-232. [PubMed: 19028798] 
46. Xiao L, Pimentel DR, Wang J, Singh K, Colucci WS, Sawyer DB. Role of reactive oxygen species and $\mathrm{Nad}(\mathrm{p}) \mathrm{h}$ oxidase in alpha(1)-adrenoceptor signaling in adult rat cardiac myocytes. Am J Physiol Cell Physiol 2002;282:C926-934. [PubMed: 11880281]

47. Simao S, Fraga S, Jose PA, Soares-da-Silva P. Oxidative stress plays a permissive role in alpha2adrenoceptor-mediated events in immortalized shr proximal tubular epithelial cells. Mol Cell Biochem 2008;315:31-39. [PubMed: 18491035]

48. Jackson EK, Gillespie DG, Zhu C, Ren J, Zacharia LC, Mi Z. Alpha2-adrenoceptors enhance angiotensin II-induced renal vasoconstriction: Role for Nadph oxidase and RhoA. Hypertension 2008;51:719-726. [PubMed: 18250367]

49. Diaz-Cruz A, Guinzberg R, Guerra R, Vilchis M, Carrasco D, Garcia-Vazquez FJ, Pina E. Adrenaline stimulates H2O2 generation in liver via Nadph oxidase. Free Radic Res 2007;41:663672. [PubMed: 17516239]

50. Zeng C, Villar VA, Yu P, Zhou L, Jose PA. Reactive oxygen species and dopamine receptor function in essential hypertension. Clin Exp Hypertens 2009;31:156-178. [PubMed: 19330604]

51. Shankland SJ, Pippin JW, Reiser J, Mundel P. Podocytes in culture: Past, present, and future. Kidney Int 2007;72:26-36. [PubMed: 17457377]

52. Huber TB, Gloy J, Henger A, Schollmeyer P, Greger R, Mundel P, Pavenstadt H. Catecholamines modulate podocyte function. J Am Soc Nephrol 1998;9:335-345. [PubMed: 9513895]

53. Endlich N, Endlich K. Camp pathway in podocytes. Microsc Res Tech 2002;57:228-231. [PubMed: 12012389]

54. Nishino T. The conversion of xanthine dehydrogenase to xanthine oxidase and the role of the enzyme in reperfusion injury. J Biochem 1994;116:1-6. [PubMed: 7798166]

55. Nishino T, Okamoto K, Kawaguchi Y, Hori H, Matsumura T, Eger BT, Pai EF. Mechanism of the conversion of xanthine dehydrogenase to xanthine oxidase: Identification of the two cysteine disulfide bonds and crystal structure of a non-convertible rat liver xanthine dehydrogenase mutant. J Biol Chem 2005;280:24888-24894. [PubMed: 15878860]

56. Forstermann U, Munzel T. Endothelial nitric oxide synthase in vascular disease: From marvel to menace. Circulation 2006;113:1708-1714. [PubMed: 16585403]

57. Serrander L, Cartier L, Bedard K, Banfi B, Lardy B, Plastre O, Sienkiewicz A, Forro L, Schlegel W, Krause KH. Nox4 activity is determined by mRNA levels and reveals a unique pattern of ros generation. Biochem J 2007;406:105-114. [PubMed: 17501721]

58. Tyler BJ. Reaction of hydrogen peroxide and nitric oxide. Nature 1962;195:279-280.

59. Noronha-Dutra AA, Epperlein MM, Woolf N. Reaction of nitric oxide with hydrogen peroxide to produce potentially cytotoxic singlet oxygen as a model for nitric oxide-mediated killing. FEBS Lett 1993;321:59-62. [PubMed: 8385630]

60. Fulton D, Gratton JP, Sessa WC. Post-translational control of endothelial nitric oxide synthase: Why isn't calcium/calmodulin enough? J Pharmacol Exp Ther 2001;299:818-824. [PubMed: 11714864]

61. Queen LR, Ji Y, Xu B, Young L, Yao K, Wyatt AW, Rowlands DJ, Siow RC, Mann GE, Ferro A. Mechanisms underlying beta2-adrenoceptor-mediated nitric oxide generation by human umbilical vein endothelial cells. J Physiol 2006;576:585-594. [PubMed: 16873402]

62. Sethi R, Adameova A, Dhalla KS, Khan M, Elimban V, Dhalla NS. Modification of epinephrineinduced arrhythmias by $\mathrm{N}$-acetyl-L-cysteine and vitamin E. J Cardiovasc Pharmacol Ther 2009;14:134-142. [PubMed: 19339682]

63. Jewett SL, Eddy LJ, Hochstein P. Is the autoxidation of catecholamines involved in ischemiareperfusion injury? Free Radic Biol Med 1989;6:185-188. [PubMed: 2496008]

64. Youdim MB, Edmondson D, Tipton KF. The therapeutic potential of monoamine oxidase inhibitors. Nat Rev Neurosci 2006;7:295-309. [PubMed: 16552415]

65. Remondino A, Kwon SH, Communal C, Pimentel DR, Sawyer DB, Singh K, Colucci WS. Betaadrenergic receptor-stimulated apoptosis in cardiac myocytes is mediated by reactive oxygen species/c-Jun NH2-terminal kinase-dependent activation of the mitochondrial pathway. Circ Res 2003;92:136-138. [PubMed: 12574140] 
66. Amin JK, Xiao L, Pimental DR, Pagano PJ, Singh K, Sawyer DB, Colucci WS. Reactive oxygen species mediate alpha-adrenergic receptor-stimulated hypertrophy in adult rat ventricular myocytes. J Mol Cell Cardiol 2001;33:131-139. [PubMed: 11133229]

67. Heumuller S, Wind S, Barbosa-Sicard E, Schmidt HH, Busse R, Schroder K, Brandes RP. Apocynin is not an inhibitor of vascular Nadph oxidases but an antioxidant. Hypertension 2008;51:211-217. [PubMed: 18086956]

68. D'Agostino RB Sr. Vasan RS, Pencina MJ, Wolf PA, Cobain M, Massaro JM, Kannel WB. General cardiovascular risk profile for use in primary care: The Framingham heart study. Circulation 2008;117:743-753. [PubMed: 18212285] 
Targeted ablation of the Chga locus in the mouse: Coordinate effects on $\mathrm{H}_{2} \mathrm{O}_{2}$ and isoprostane formation


Amplex Red fluorescence/creatinine

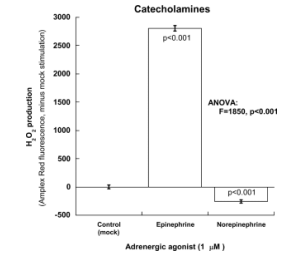

Synthetic adrenergic agonists



Adrenergic agonist $(1 \mu \mathrm{M})$ 
Figure 1.

A. Chga targeted ablation on $\mathrm{H}_{2} \mathrm{O}_{2}$ and lipid peroxidation (isoprostane). Urine isoprostane and $\mathrm{H}_{2} \mathrm{O}_{2}$ measured and normalized by creatinine. WT vs $\mathrm{KO}: \mathrm{H}_{2} \mathrm{O}_{2}(\mathrm{p}<0.02)$ and isoprostane $(\mathrm{p}<0.002),[\mathrm{n}=6$ animals/condition]. Results are shown as mean \pm one SEM. B. Renal podocytes, catecholamines and $\mathrm{H}_{2} \mathrm{O}_{2}$. Catecholamines (both epinephrine and norepinephrine; each at $1 \mu \mathrm{M}$ ) were used to influence $\mathrm{H}_{2} \mathrm{O}_{2}$ production in mouse podocytes ( $n=6$ replicate wells per condition). Results are shown as mean \pm one SEM. C. Selective adrenergic agonists and renal podocyte $\mathrm{H}_{2} \mathrm{O}_{2}$. Selective adrenergic agonists (alpha-1: phenylephrine; alpha-2: clonidine; beta: isoproterenol), each at $1 \mu \mathrm{M}$, were used to influence $\mathrm{H}_{2} \mathrm{O}_{2}$ production in mouse podocytes ( $n=6$ replicate wells per condition). Results are shown as mean \pm one $\mathrm{SEM}$. 




Figure 2. Adrenergic outflow inhibition (clonidine) or NADPH oxidase (Nox) inhibition (apocynin) on BP

Both SBP and DBP were reduced significantly in KO mice by sympathetic inhibition with the $\alpha_{2}$-agonist clonidine $(125 \mu \mathrm{g} / \mathrm{kg}$ body weight/day for 3 weeks). SBP and DBP were reduced significantly in $\mathrm{KO}$ mice by Nox inhibitor apocynin $(2 \mathrm{mmol} / \mathrm{L})$ in drinking water for 3 weeks. $\mathrm{N}$ for each group (number of mice) is given in the figure inset. Results are shown as mean \pm one SEM. 

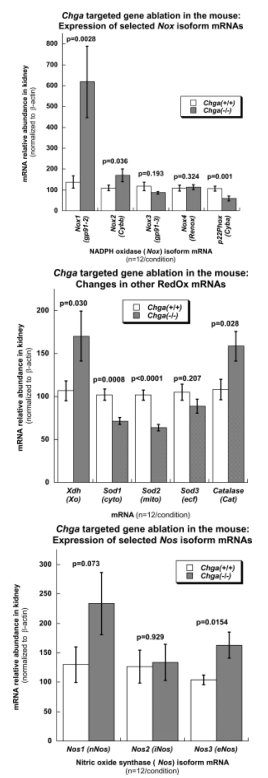

Figure 3. mRNA abundances in kidney

Relative abundances of mRNAs were normalized to $\beta$-actin in kidney by real-time PCR $\left(\mathrm{n}=12\right.$ kidneys were studied from each strain, WT or KO). Differences in $\mathrm{C}_{\mathrm{t}}$ (target mRNA versus $\beta$-actin mRNA) are expressed on a \% scale (see Methods). Results are shown as mean \pm one SEM. A. NADPH oxidase (Nox) isoforms. B. RedOx targets. C. Nos (nitric oxide synthase) isoforms. 

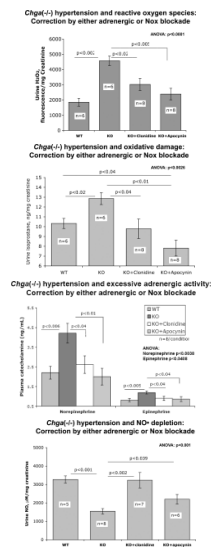

\section{Chga(-/-) hypertension and NO- depletion: Correction by either adrenergic or Nox blockade}

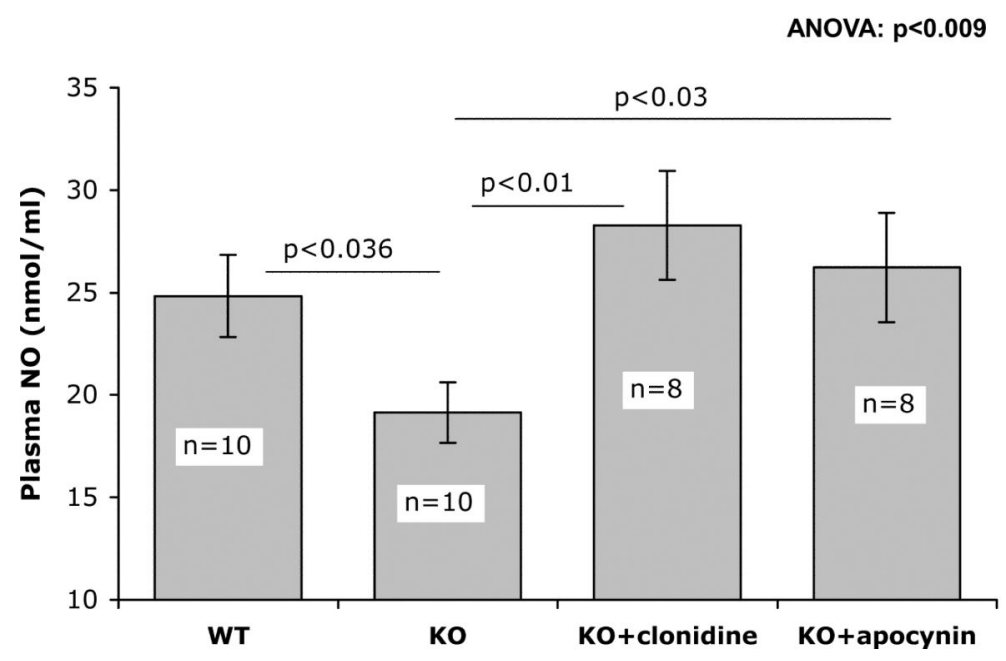

Figure 4A. Oxygen radicals $\left(\mathrm{H}_{2} \mathrm{O}_{2}\right)$ : Response to treatment by sympathetic inhibition or NADPH oxidase blockade

Urine $\mathrm{H}_{2} \mathrm{O}_{2}$ level (amplex red fluorescence/mg creatinine) is presented in WT (n=6), KO $(\mathrm{n}=6), \mathrm{KO}+$ clonidine $(\mathrm{n}=8)$, or $\mathrm{KO}+$ apocynin $(\mathrm{n}=8)$ mice. Results are shown as mean \pm one SEM. B. Lipid peroxidation (isoprostane): Response to treatment by sympathetic inhibition or NADPH oxidase (Nox) blockade. Urine isoprostane level ( $\mathrm{ng} / \mathrm{mg}$ creatinine) is presented in WT $(n=6), \mathrm{KO}(n=6), \mathrm{KO}+$ clonidine $(n=8)$, or KO+apocynin $(n=8)$ mice. Results are shown as mean \pm one SEM. C. Catecholamine secretion: Response to treatment by sympathetic inhibition or NADPH oxidase (Nox) blockade. Plasma catecholamine levels ( $\mathrm{ng} / \mathrm{ml}$ ) of WT, $\mathrm{KO}, \mathrm{KO}+$ clonidine and $\mathrm{KO}+$ apocynin mice [ $\mathrm{n}=8$ per condition] were measured by HPLC, in plasma obtained from anesthetized mice. Results are shown as mean \pm one SEM. D. Nitric oxide (NO•) depletion: Response to treatment by sympathetic inhibition or NADPH oxidase (Nox) blockade. Urinary excretion of nitrate+nitrite was taken as an index of $\mathrm{NO} \bullet$ production. Urine levels of $\mathrm{NO} \bullet(\mu \mathrm{mol} / \mathrm{mg}$ creatinine) were measured in WT $(n=5), \mathrm{KO}(\mathrm{n}=8), \mathrm{KO}+$ clonidine $(\mathrm{n}=7)$ and $\mathrm{KO}+$ apocynin $(\mathrm{n}=7)$ mice. Results are shown as mean \pm one SEM. E. Nitric oxide (NO•) depletion in the circulation: Response to treatment by sympathetic inhibition or NADPH oxidase (Nox) blockade. Plasma levels of $\mathrm{NO} \bullet(\mathrm{nmol} / \mathrm{ml})$ were measured in WT $(\mathrm{n}=10), \mathrm{KO}(\mathrm{n}=10), \mathrm{KO}+\mathrm{clonidine}(\mathrm{n}=8)$. and KO + apocynin $(n=8)$ mice. Results are shown as mean \pm one SEM. 


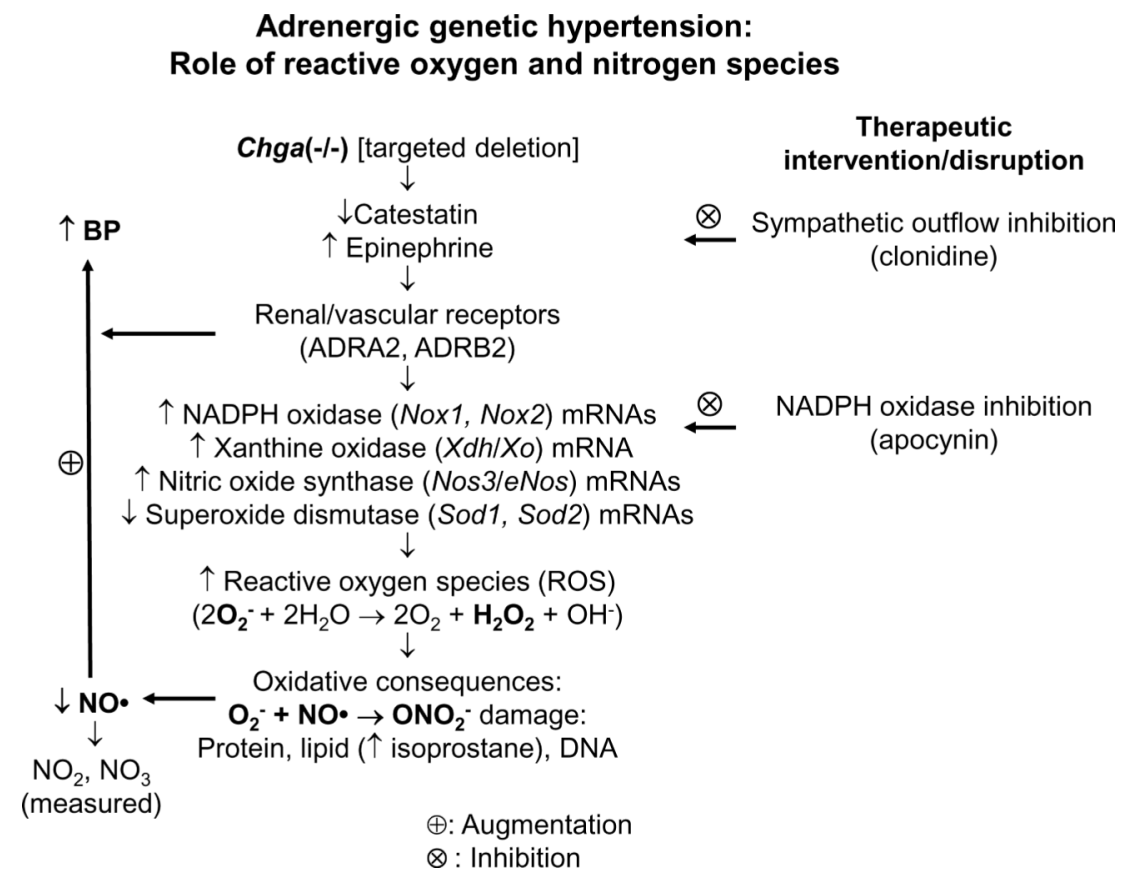

Figure 5. Oxygen radicals and hyper-adrenergic hypertension: Hypothesis integrating experimental results from this study in targeted ablation of the mouse Chga locus Directional arrows indicate proposed cause-and-effect relationships. 